\title{
角筒深絞り加エにおける可変ブランクホルダーカの最適軌道設計*
}

\author{
北山 哲士 ${ }^{* 1}$ ，喜多 健太 ${ }^{* 2}$ ，山崎 光悦 ${ }^{* 3}$
}

\section{Optimum Trajectory of the Variable Blank Holder Force in the Square Cup Deep Drawing}

\author{
Satoshi KITAYAMA ${ }^{* 1}$, Kenta KITA and Koetsu YAMAZAKI \\ ${ }^{* 1}$ Kanazawa University, College of Science and Engineering \\ Kakuma-machi, Kanazawa, 920-1192, Japan
}

In deep drawing, a low blank holder force (BHF) will cause wrinkling, while a high BHF will lead to tearing. The Variable Blank Holder Force (VBHF) is an attractive approach in the industries, and it is important to determine the VBHF trajectory. In this paper, a sequential approximate optimization (SAO) approach is employed for determining the VBHF trajectory. The objective is taken as the minimization of the deviation of whole thickness. The constraint is quantitatively defined with the Forming Limit Diagram (FLD), in which no wrinkling and tearing can be observed. The blank holder forces are taken as the design variables. Two constraints in which wrinkling and tearing are avoided are employed in this paper. The Radial Basis Function (RBF) network is employed for constructing the response surface to capture the non-linear phenomena. In the proposed SAO approach, the optimum BHF is added to refine the VBHF trajectory, while some data points are also added to cover the entire design variable space. The result of the VBHF trajectory with the proposed SAO approach is compared with the one of the closed-loop type algorithm.

Key Words : Deep Drawing, Finite Element Method, Computational Mechanics, Plastic Working, Computer Aided Engineering, Computer Aided Analysis, Engineering Optimization

\section{1. 緒言}

大型プレス機は，自動車のドアパネルの加工をはじめ，様々な用途で用いられている．板材を抑えるブランク ホルダー力（Blank Holder Force: BHF）は，材料加工中，一定であることが多く，板材にしわや割れを発生させな いような適切な BHF を決めるには，試行錯誤を要する. そのため, コンピュータシミュレーション $(\mathrm{CAE}) を$ 用い て，事前に十分な検討を行っておき，実機による加工が行われることが多い，一方，サーボプレス機は，従来の プレス機と異なり，ストロークに㐫じて BHF を可変させることができるため，しわや割れを防ぐような可変ブラ ンクホルダーカ(Variable Blank Holder Force: VBHF)による加工が可能である.

Wang らは，BHF の大きさ・ストローク・加工材料に発生する割れ・しわの間には，基本的には図 $1(\mathrm{a}) \sim(\mathrm{d}) に$ 示すような関係があると指摘している(1). すなわち, 加工材料には, 割れやしわが発生しないような領域が存在 し(図 1 中の Safety Region), その領域内で BHF の大きさを設定すれば割れやしわが発生しないこと, また Obermeyer らによれば，最小 BHFで加工することが良いとされている(2).このことを達成するためには，図 1 か ら明らかなように，BHFの大きさをストロークに応じて変化させる必要がある. しかし，ストロークとしわ・割 れの関係は一般には未知であるため, 最小 BHF の軌道を求めることは非常に難しく, 実機を通じて最小 BHF の 軌道を求めることは，時間やコストの観点から好ましくない，そのため，CAE 技術を用いて，最小 BHF の軌道 を求めることが望ましい.

VBHF の軌道を求める研究は，大きく二つに大別することができる.

* 原稿受付 2010 年 8 月 4 日

*1 正員, 金沢大学理工研究域（广920-1192 石川県金沢市角間町）

*2 学生員, 金沢大学大学院自然科学研究科

*3 正員, フェロー, 金沢大学理工研究域

E-mail: kitagon@t.kanazawa-u.ac.jp 


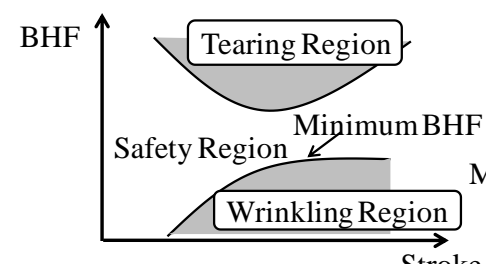

(a)

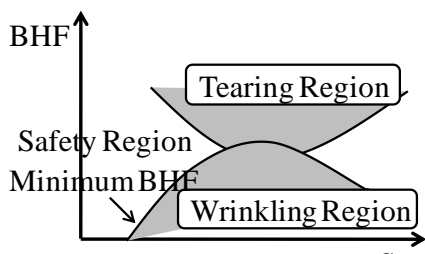

(c)

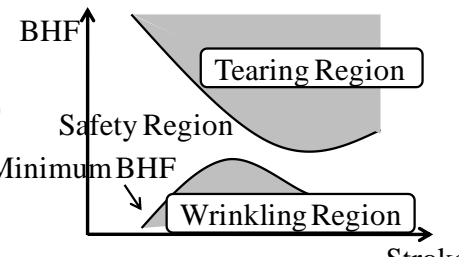

(b)

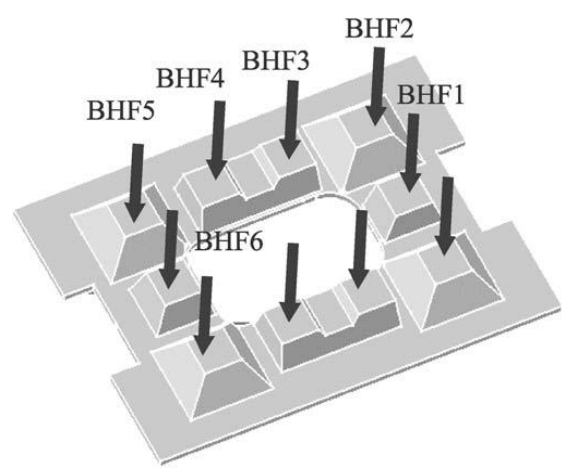

Fig.2 Segmented blank holder forces

Fig.1 Four basic types of BHF formability windows

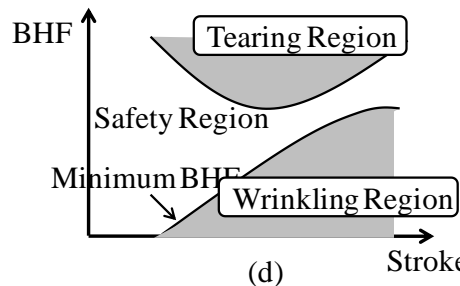

(d)

（1）閉ループ型のアルゴリズムを構築し，VBHF の軌道を求める研究 ${ }^{(1,3-9)}$.

（2）応答曲面法を用いて近似的な BHF の大きさやVBHF の最適軌道を求める研究 ${ }^{(10-20)}$.

筆者らは，角筒深絞り加工を対象とした簡素な閉ループ型アルゴリズムを構築し，その有効性を数值シミュレ ーションおよび実験を通じて検討した(9).この研究では，板材の板厚変動を考慮し，加工中の板厚変動が一定值 以上であれば，BHFを下げるという仕組みを組み込んでおり，数值シミュレーションの結果を基にサーボプレス 機による実験を行った結果，両者は極めてよい一致をみた.この研究の特徵は，成形加工中の板厚変動を逐次的 にチェックするため, きめ細かな BHF の制御が可能であり, 詳細な VBHF の軌道を得ることができた. 一方で, 簡素なアルゴリズムであるにも関わらず，アルゴリズムの自動化は極めて困難であり，また板厚変動を判断する パラメータの設定指針が決めづらいなどの課題も同時に残されていた.

一方，応答曲面法による研究は，成形限界線図(Forming Limit Diagram: FLD)を用いて，成形加工終了時におけ る材料のひずみ状態から，目的関数や制約条件等を定量的に評価し，目的関数や制約条件を応答曲面近似し，応 答曲面の最適解を最終的な BHF の大きさとする方法である. 閉ループ型アルゴリズムでは, 成形加工中の材料の 状態を考慮できるため，VBHF の軌道を求めるのは比較的容易であるが，応答曲面法によるアプローチでは，例 えば図 2 に示すように, 板材に作用する BHF を分割し, 各 BHF に対して適切な大きさを決定する研究が多く(10-17), ストロークに応じて BHF を変化させるといった VBHF の最適軌道設計に関する研究は極めて少ない(18). これは, 応答曲面法によるアプローチでは，成形終了時の状態における FLD を活用しているためであり，閉ループ型アル ゴリズムのように成形加工中の板材の状態までは考慮できないこと，また VBHF の最適軌道を求めるとなると設 計変数の取り方自体が難しく，場合によっては設計変数の数が多くなってしまうため，応答曲面によるアプロー チが困難となってしまうためであると考えられる．また，従来の応答曲面法を用いた研究では，下記の点で課題 が残されているものと考えている.

(P1) しわや割れの危険性を目的関数の一つとして考えているが(10,11,14-20)，これらは本来，制約条件として扱う ほうが自然である。

(P2) 複数の目的関数を設定し, 線形加重和法を用いて, 単一目的関数の最小化問題に変換している ${ }^{(10,14,16-19)}$. 線形加重和法における重みの決定について，何ら指針が得られておらず，一組の重みを設定して最適化 を終了している．重みに関する有効な知見，すなわち，目的関数間のトレードオフ関係について，何ら 言及されていない.

(P3) 多くの研究では，複数存在する目的関数の応答曲面作成において，二次多項式近似が基本となっており， 交互作用等に関する注意が払われていない(10-16,20). 近年, Kriging や Support Vector Machine を用いた研究 が報告されているが(17-19), BHF の大きさを求める研究であり, VBHF の最適軌道を求める研究ではない.

(P4) 逐次近似最適化のアプローチが取られている研究も行われているが(10,12,15,16), これらの研究では，応答曲 面の最適解のみを追加してゆくZ Zooming 法である(21). 解の精度および近似的な大域的最適解を得たいの 
であれば，応答曲面の最適解に加え，サンプル点の疎な領域にもサンプル点を追加する逐次近似最適化 を行うことが望ましい.

(P5) 応答曲面法によるVBHF の最適軌道と閉ループ型アルゴリズムによるVBHF の軌道を比較することで, 両者の相違点もしくは類似点の議論が可能となる.

そこで, 本論文では上記の課題点を踏まえ, 逐次近似最適化の考えに基づき，近似的な VBHF の最適軌道を設 計する. 逐次近似最適化の方法として, 筆者らが取り組んでいる RBF ネットワークによる逐次近似最適化システ ムを用いる(22)，第 2 章では，本論文で用いる有限解析モデル等について概説する．第 3 章において，応答曲面法 によるVBHF の最適軌道設計問題について詳述する. 数值計算例を通じ, 逐次近似最適化システムによって得ら れた近似的な VBHF の最適軌道を示し, 閉ループ型アルゴリズムによって得られたVBHF の軌道との相違につい て考察する．塑性解析シミュレーションには，動的有限要素解析ソフト LS-DYNA を用いた.

\section{2. 解析モデルおよび諸条件}

\section{$2 \cdot 1$ 実成形品}

本論文で対象とする角筒深絞りの実際の成形品及びダイス・カウンターパンチの寸法を図 3 と図 4(a), (b)に示す.

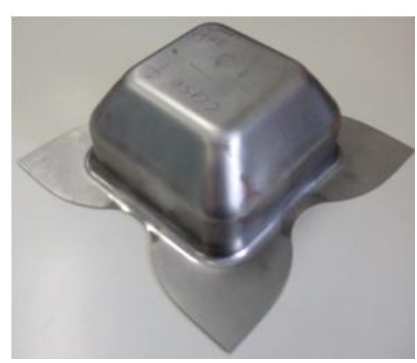

Fig.3 Rectangular cup

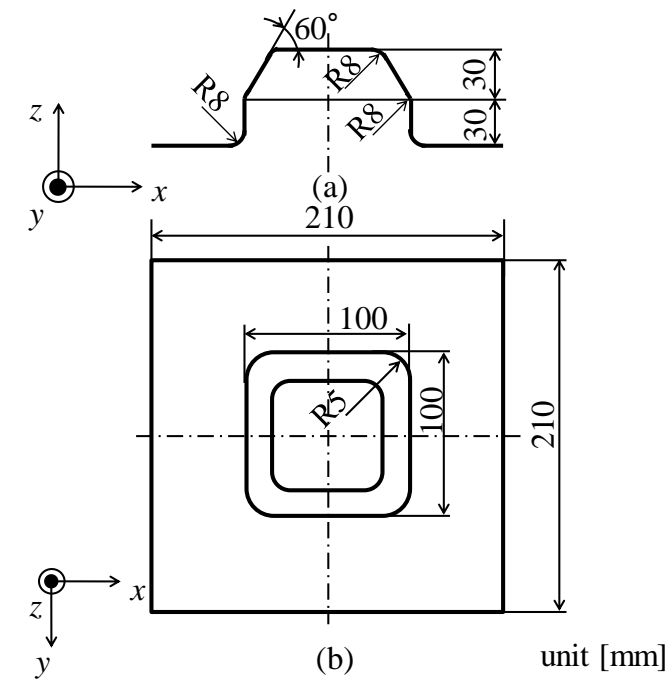

Fig.4 Dimensions of the die and counterpunch

\section{$2 \cdot 2$ 材料特性}

使用する材料は高強度鋼板(SPFC440)であり，材料特性（実測值）を表 1 に示す．応力一ひずみの関係は式(1) であらわされる。

$$
\sigma=793 \varepsilon^{0.189}
$$

Table 1 Material properties of SPFC440

\begin{tabular}{c|c}
\hline \hline Density: $\rho\left[\mathrm{kg} / \mathrm{mm}^{3}\right]$ & $7.84 \times 10^{-6}$ \\
\hline Young's modulus: $E[\mathrm{MPa}]$ & $2.06 \times 10^{5}$ \\
\hline Poisson's ratio: $\nu$ & 0.3 \\
\hline Yield stress: $\sigma_{Y}[\mathrm{MPa}]$ & 353 \\
\hline Tensile strength: $\sigma_{T}[\mathrm{MPa}]$ & 479 \\
\hline Normal anisotropy coefficient: $r$ & 0.98 \\
\hline Strain hardening coefficient: $n$ & 0.189 \\
\hline
\end{tabular}




\section{$2 \cdot 3$ 有限要素モデルと精度}

金型形状から作成した有限要素モデルの概要を図 5(a),(b)に, 各モデルの要素タイプおよび要素数を表 2 に示す. 対称性を考慮し，解析には $1 / 4$ モデルを採用している．板材の寸法は $92.5 \mathrm{~mm} \times 92.5 \mathrm{~mm} \times 1.2 \mathrm{~mm}$ とし，板材とパ ンチブランクホルダー/カウンターパンチの摩擦係数はすべて 0.1 とした．また，接触に関しては，ペナルティ法 を用い, ペナルティ係数は 0.1 とした. 板材はシェル要素(Belytschko-Tsay)を用い, 板厚方向の積分点数は 7 点と した.

Table 2 Element type and number of finite elements

\begin{tabular}{l|c|c}
\hline \hline & Element type & Number of finite elements \\
\hline Counter punch & Rigid & 120 \\
\hline Dies & Rigid & 924 \\
\hline Blank & Shell (Belytschko-Tsay) & 2116 \\
\hline Blank holder & Rigid & 432 \\
\hline Punch & Rigid & 962 \\
\hline
\end{tabular}

図 5 において，パンチは固定され，ブランクホルダーカは，ブランクホルダー全体に， $z$ 軸正の方向に作用寸 る. カウンターパンチとダイスに $z$ 軸負の方向へ強制変位を与え, 下死点まで到達した後, カウンターパンチ・ ダイス・ブランクホルダーに対し， $z$ 軸正の方向へ強制変位を与えることで，加工は終了する． BHF $=100 k N$ 一定 で加工した際の加工終了後の材料(1/4 モデル) を図 6(a),(b)に示す. 図 6(a)はシミュレーションによる結果, 図 6(b) は実験結果であり，寸法誤差を表 3 に示寸．また図 7 に示寸測定点における板厚誤差を表 4 に示す。これらの結 果より, 本論文で用いるシミュレーションモデルは妥当であると考える.
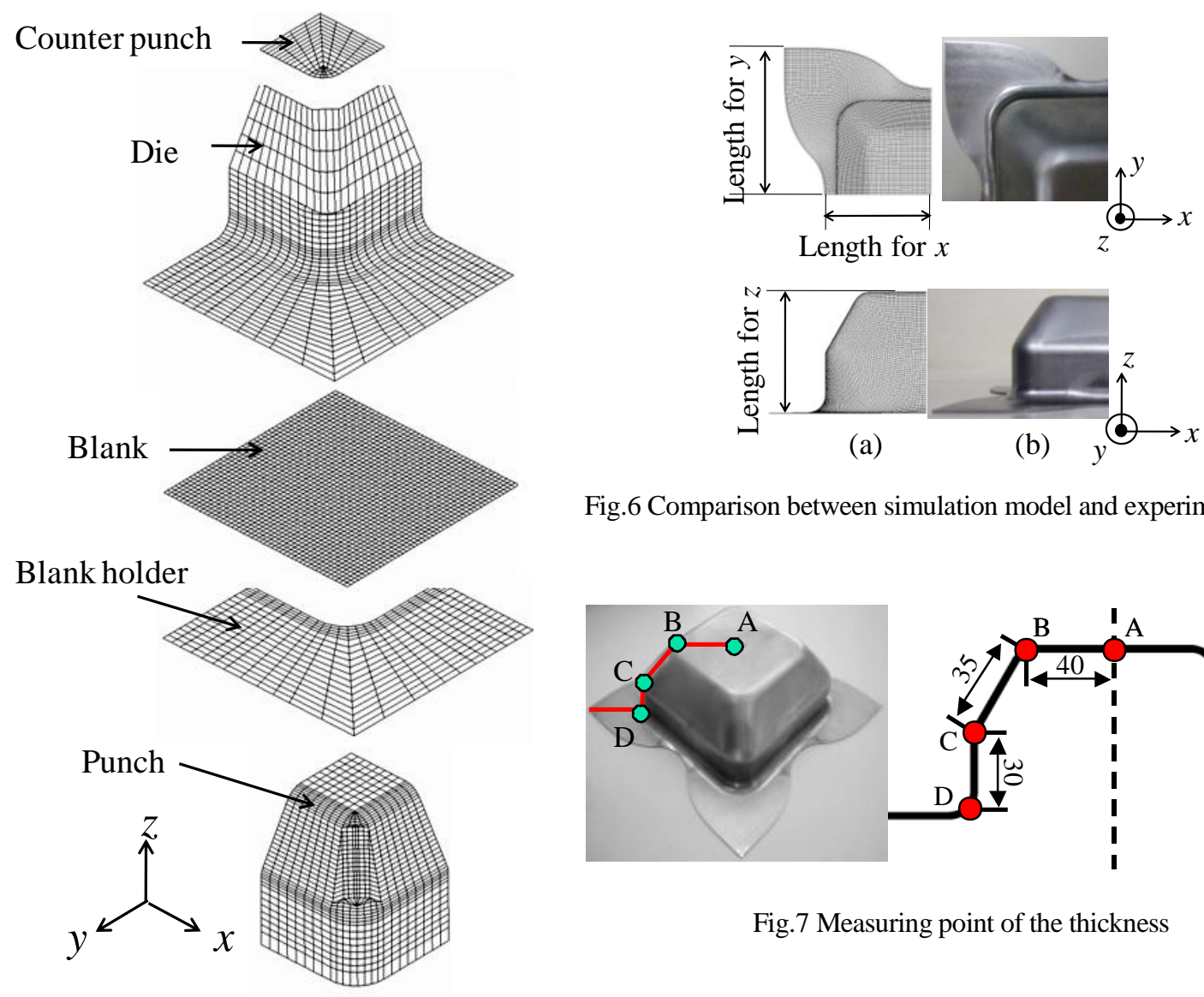

Fig.6 Comparison between simulation model and experiment

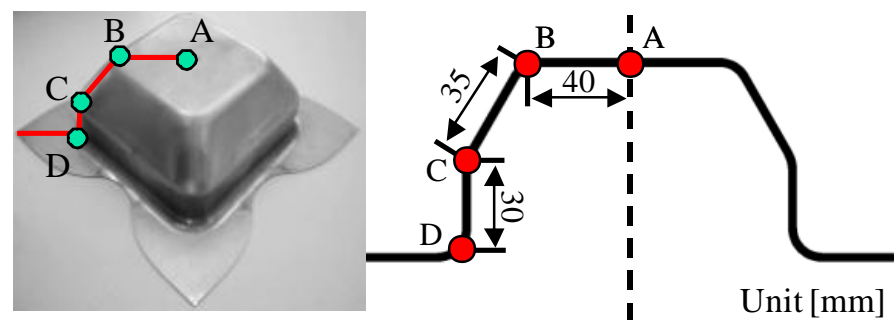

Fig.7 Measuring point of the thickness

Fig.5 Finite element models 
Table 3 Errors of length

\begin{tabular}{l|l}
\hline \hline Error for $\mathrm{x}$-direction & $3.3[\%]$ \\
\hline Error for $\mathrm{y}$-direction & $0.1[\%]$ \\
\hline Error for z-direction & $1.2[\%]$ \\
\hline
\end{tabular}

Table 4 Errors of thickness between simulation and experiment

\begin{tabular}{l|c|c|c|c}
\hline \hline Measuring point & A & B & C & D \\
\hline Simulation $[\mathrm{mm}]$ & 1.12 & 0.93 & 1.12 & 1.35 \\
\hline Experiment [mm] & 1.14 & 0.93 & 1.11 & 1.30 \\
\hline Error [\%] & 1.75 & 0.00 & 0.90 & 3.85 \\
\hline
\end{tabular}

\section{2・4 モーション設定}

ダイスとカウンターパンチの実験におけるモーション設定を図 8 に示す. 解析でも同じモーション設定を標準 として用いている．材料とブランクホルダーが接触し始め，下死点まで到達し，材料とブランクホルダーの接触 が終了するまでの時刻を対象とした. 解析中において, ダイスとカウンターパンチの初期速度 $v_{\text {init }} \mathrm{mm} / \mathrm{s}$ と最大速 度 $v_{\max } m m / s$ はそれぞれ次の通りである.

$$
\begin{aligned}
& v_{\text {init }}=267 \\
& v_{\max }=359
\end{aligned}
$$

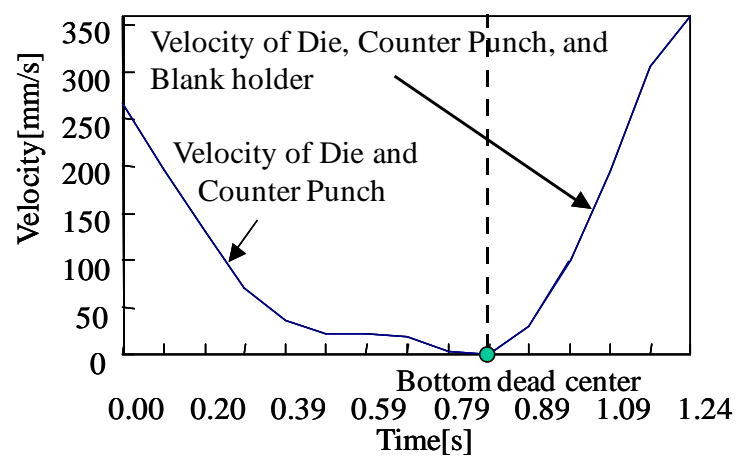

Fig.8 Motion of the die, blank holder, and counter punch

\section{$2 \cdot 5$ しわの発生}

シミュレーションにおいて，しわが発生したときの状況を図 9 に示す。このとき，BHF=20kN一定であり，実 験においてもしわが発生している（図 10）。このことからも，本研究で用いる有限要素解析モデルの妥当性がう かがえる。

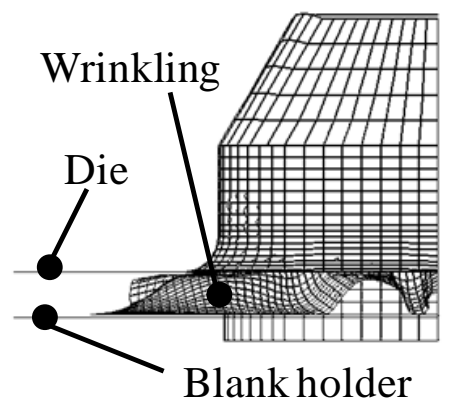

Fig.9 Wrinkling by the simulation

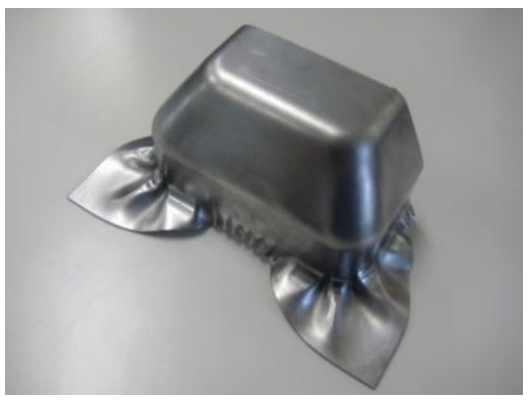

Fig.10 Wrinkling in the experiment

\section{VBHF の最適軌道設計問題}

本章では，応答曲面法を用いた近似的な VBHF の最適軌道設計問題について詳述する．また，材料の有限要素 の数を $m$ と表記する.

\section{$3 \cdot 1$ 最適設計問題の定式化}

本論文で扱う近似的な VBHF の最適軌道設計を次のように定式化する. 


$$
\begin{aligned}
& f(\boldsymbol{x}) \rightarrow \min \\
& x_{i}^{L} \leq x_{i} \leq x_{i}^{U} \quad i=1,2, \cdots, n d v \\
& g_{j}(\boldsymbol{x}) \leq 0 \quad j=1,2, \cdots, \text { ncon }
\end{aligned}
$$

ここで $f(\boldsymbol{x})$ は最小化する目的関数， $\boldsymbol{x}$ は設計変数ベクトル， $g_{j}(\boldsymbol{x})$ は挙動制約条件を表す．また， $x_{i}^{L} と x_{i}^{U}$ は $i$ 番目の設計変数べクトル $x_{i}$ に直接的に課せられる側面制約条件であり, $n d v$ は設計変数の数, ncon は挙動制約 条件の数を表す.

\section{$3 \cdot 2$ 目的関数}

一般に深絞り加工では，パンチ角部において板厚が最も減少し，割れが発生しやすい。そこで最小板厚を最大 化するような目的関数も考えられるが，その場合，最小板厚のみに着目しているため，板材全体の板厚を考慮す ることができない. そこで, 成形加工終了時における板厚変動を最小化するような次の目的関数を採用する ${ }^{(14-17) .}$

$$
f(\boldsymbol{x})=\left\{\sum_{i=1}^{m}\left(t_{i} / t_{0}-1\right)^{p}\right\}^{1 / p}
$$

式(7)中において， $t_{0}$ は初期板厚を表わし， $t_{i}$ は成形終了時における $i$ 番目の有限要素の板厚を表す。また $p$ は 目的関数の極值を強調するパラメータであり， $p=2,4,6, \cdots$ とされている. 本論文では，文献(14), (16)で用いられ ている值 $(p=4)$ を採用した.

\section{$3 \cdot 3$ 設計変数}

VBHF の軌道を求めるため，本論文では，ストローク長をいくつかに分割し，各ストロークにおける BHFの大 きさを決定することで, VBHF の軌道を求めることにした．ストローク長を $L_{\max }$ と表記する. $L_{\max }$ を $n$ 分割し， $i$ ストロークにおける BHF の大きさを設計変数とする．具体的な設計変数の様子を図 11 に示す.

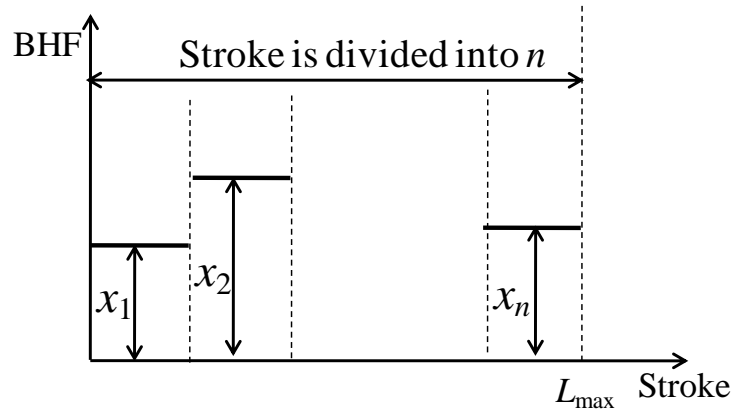

Fig.11 An example of the design variables

\section{$3 \cdot 4$ 制約条件}

本論文では，しわや割れの危険性をそれぞれ，制約条件として扱うことにする.これらを定量的に扱うために， FLD を用いて制約条件值を求める. 制約条件值の算出方法について図 12 を用いて説明する.

図 12 中において，しわの危険性が予測される有限要素は，しわ領域(Wrinkling region)にプロットされ，一方， 割れの危険性が予測される有限要素は，割れ領域(Tearing region)にプロットされる．また，しわや割れがないと予 測される有限要素は，安全領域(Safety region)の中にプロットされる。主ひずみ $\varepsilon_{1}$ は,

$$
\begin{aligned}
& \varepsilon_{1}=\varphi_{T}\left(\varepsilon_{2}\right) \\
& \varepsilon_{1}=\varphi_{W}\left(\varepsilon_{2}\right)
\end{aligned}
$$


と表記される，ここで $\varphi_{T}$ は，割れを制御する成形限界曲線(Forming Limit Curve: FLC)を表し， $\varphi_{T}$ と $\varphi_{W}$ は用い る材料に依存する.ここで, 安全係数 $s$ を考慮した次の関数を考える.

$$
\begin{aligned}
& \theta_{T}\left(\varepsilon_{2}\right)=(1-s) \varphi_{T}\left(\varepsilon_{2}\right) \\
& \theta_{W}\left(\varepsilon_{2}\right)=(1+s) \varphi_{W}\left(\varepsilon_{2}\right)
\end{aligned}
$$

しわと割れの危険性を，以下のようにして，それぞれ個別に定量的に評価した。

（a）割れの危険性評価について： 割れの危険性に関する制約条件 $g_{1}(\boldsymbol{x})$ を下記のようにして評価する.

$$
g_{1}(\boldsymbol{x})=\left(\sum_{j=1}^{m} T_{j}\right)^{1 / p}
$$

ただし，

$$
\begin{aligned}
& T_{j}=\left(\varepsilon_{1}^{j}-\theta_{T}\left(\varepsilon_{2}^{j}\right)\right)^{p} \quad \varepsilon_{1}^{j}>\theta_{T}\left(\varepsilon_{2}^{j}\right) \\
& T_{j}=0 \quad \text { otherwise }
\end{aligned}
$$

\section{である.}

(b)しわの危険性評価について： しわの危険性に関する制約条件 $g_{2}(\boldsymbol{x})$ を下記のようにして評価する.

$$
g_{2}(\boldsymbol{x})=\left(\sum_{j=1}^{m} W_{j}\right)^{1 / p}
$$

ここで,

$$
\begin{aligned}
& W_{j}=\left(\theta_{W}\left(\varepsilon_{2}^{j}\right)-\varepsilon_{1}^{j}\right)^{p} \quad \varepsilon_{1}^{j}<\theta_{W}\left(\varepsilon_{2}^{j}\right) \\
& W_{j}=0 \text { otherwise }
\end{aligned}
$$

である.

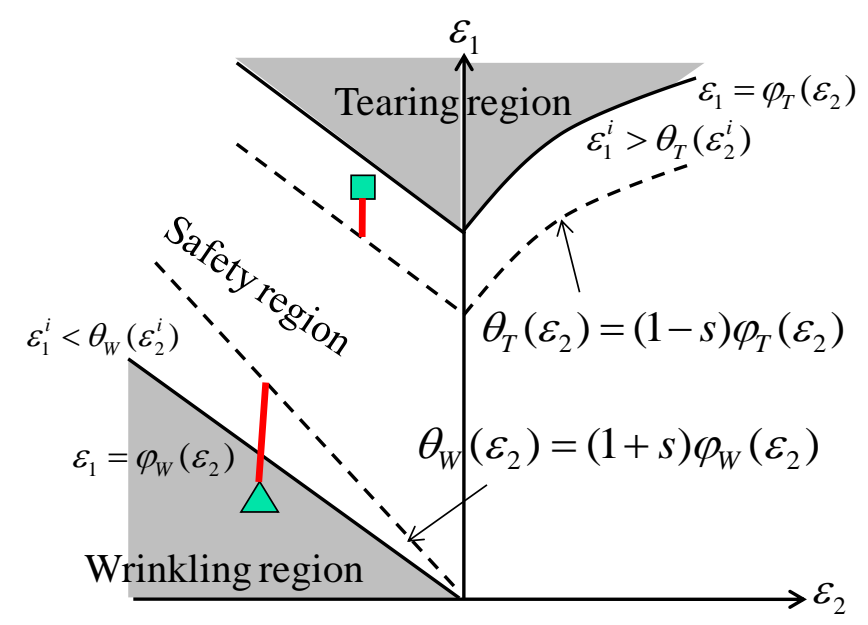

Fig.12 Constraint with the Forming Limit Diagram

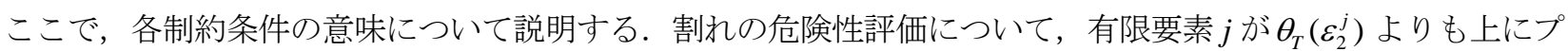
ロットされた場合(図 12 中の畐), 割れの危険性があると判断され, 式(13)により有限要素 $j$ の危険性が計算され る. すべての有限要素に関し, 式(13), (14)が計算され, その総和を考えることで割れに関する制約条件值 $g_{1}(\boldsymbol{x})$ が

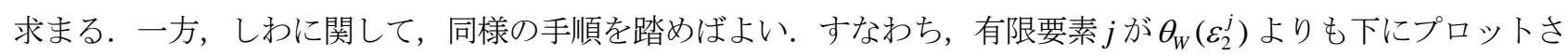


れた場合（図 12 中のム），しわの危険性があると判断され，式(16)により有限要素 $j$ の危険性が計算される. す心゙ ての有限要素に関し，式(16), (17)が計算され，その総和を考えることで，しわに関する制約条件值 $g_{2}(\boldsymbol{x})$ が求ま る. また図 12 中の安全領域(Safety region)にプロットされた有限要素については, 式(14)もしくは式(17)が適用さ れ，割れもしわも危険性はないと判断される. 式(12)，(15)中の $p$ は目的関数の場合と同様の性質をもつパラメー タであり, 目的関数值の評価と併せるため, $p=4$ とした.

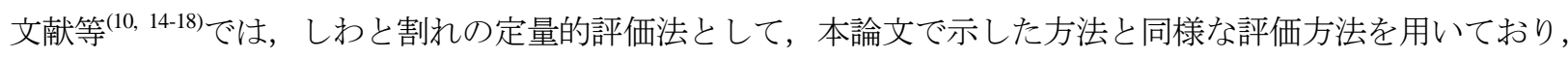
それらを目的関数の一つとしており, 線形加重和法により, 単一の目的関数を最小化する問題を設定している. 多目的最適化における制約法では，複数ある目的関数の中から一つの目的関数だけを残し，残りの目的関数を制 約条件とする方法であり，本論文は，しわや割れの危険性を制約条件として扱っていることから，制約法を用い た例の一つである，実際の成形では，製品に発生したしわは切り落とすことなどの対処により，ある程度は許容 されているものの，割れは許容されていない．しわと割れの危険性を一つの制約条件として扱った場合，しわの 危険性が高いのか，割れの危険性が高いのかを判断することが困難となり，割れとしわのどちらの危険度が高い のかを明確に扱うため, これらを個別の制約条件として扱った. 当然のことながら, 3.2 節の目的関数に加え，し わや割れの危険性を最小化するという問題を考えた場合，しわと割れの危険性は，個別の目的関数としてとらえ ることになるが，多目的最適化におけるトレードオフ分析の手間を省くため，本論文では，単一の目的関数を設 定した.

\section{$3 \cdot 5$ 全体の流れ}

近似的な大域的最適解を得るため, 筆者らはRBF ネットワークを用いた逐次近似最適化システムを提案してい る(22). 詳細は文献 (22) を参照されたい. 本論文で対象とするVBHFの最適軌道設計問題を対象として, 全体の 流れを以下に示す，以下の流れの中で, サンプル点とは, BHF の大きさやストローク長の組合せを意味しており

(図 11 参照), シミュレーション回数と同意である.

(STEP1) 初期サンプル点を Latin Hypercube Design (LHD)によって決定.

(STEP2) 目的関数值および制約条件值を算出.

(STEP3) 目的関数および制約条件の応答曲面をRBFネットワークで作成. 応答曲面の最適解を探索.

(STEP4) 応答曲面の最適解を新たなサンプル点として追加. また，サンプル点の疎な領域を見つけるため, 密 度関数を作成し, 密度関数の最適解も新たなサンプル点として追加.

(STEP5) 最大サンプル点数に到達したら終了．そうでなければ，STEP2へ戻る.

応答曲面および密度関数の最適解探索には, Differential Evolution (DE)を用いた.

\section{4. 数值シミュレーション}

本章では, 数值シミュレーションを通じて, VBHFの最適軌道を求める. 全ストローク長を $L_{\max }=62 \mathrm{~mm}$ し, 6 分割した場合の VBHF の最適軌道を求めることにする. また実験結果を参考に, BHF の大きさの上限值は, 割れ が発生した $150 \mathrm{kN}$, 下限值はしわが発生した $20 \mathrm{kN}$ と設定した．数值シミュレーションでは，割れの判定值とし て, 初期板厚の $75 \%(0.90 \mathrm{~mm})$ を下回ったとき, 割れと判定した. また，しわの発生については，ブランクホル ダーとダイスの距離を用い, 初期板厚の $120 \%(1.44 \mathrm{~mm})$ 以上になった場合, しわが発生するものと想定した.

\section{$4 \cdot 1$ 制約条件が二つの場合}

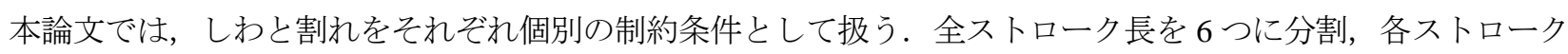
における BHFの大きさを設計変数とする. ダイスとカウンターパンチの速度変化を考慮し, 各ストローク長 $L_{i} m m$ $(i=1,2, \cdots, 6)$ は，それぞれ下記のように設定した.

$$
\begin{aligned}
& 0.00 \leq L_{1} \leq 10.09 \\
& 10.09 \leq L_{2} \leq 21.07 \\
& 21.07 \leq L_{3} \leq 31.93
\end{aligned}
$$




$$
\begin{aligned}
& 31.93 \leq L_{4} \leq 41.61 \\
& 41.61 \leq L_{5} \leq 51.50 \\
& 51.50 \leq L_{6} \leq 62.00
\end{aligned}
$$

はじめに 15 点の初期サンプル点（各ストロークにおけるBHF の大きさ）をLHDによって決め，最大サンプ ル点数を 30 とした場合, 最終的に得られた VBHF の最適軌道と成形状態を図 13 に示す，なお同図中には，筆者 らが開発した閉ループ型アルゴリズムによって得られた VBHF の軌道(点線)も併せて示してある.また, 図 14(a), (b)に板厚の分布及び最小值, 図 13 に示した $s=0.2$ における VBHF の最適軌道によって得られた成形品の FLDを 図 15 に示す.

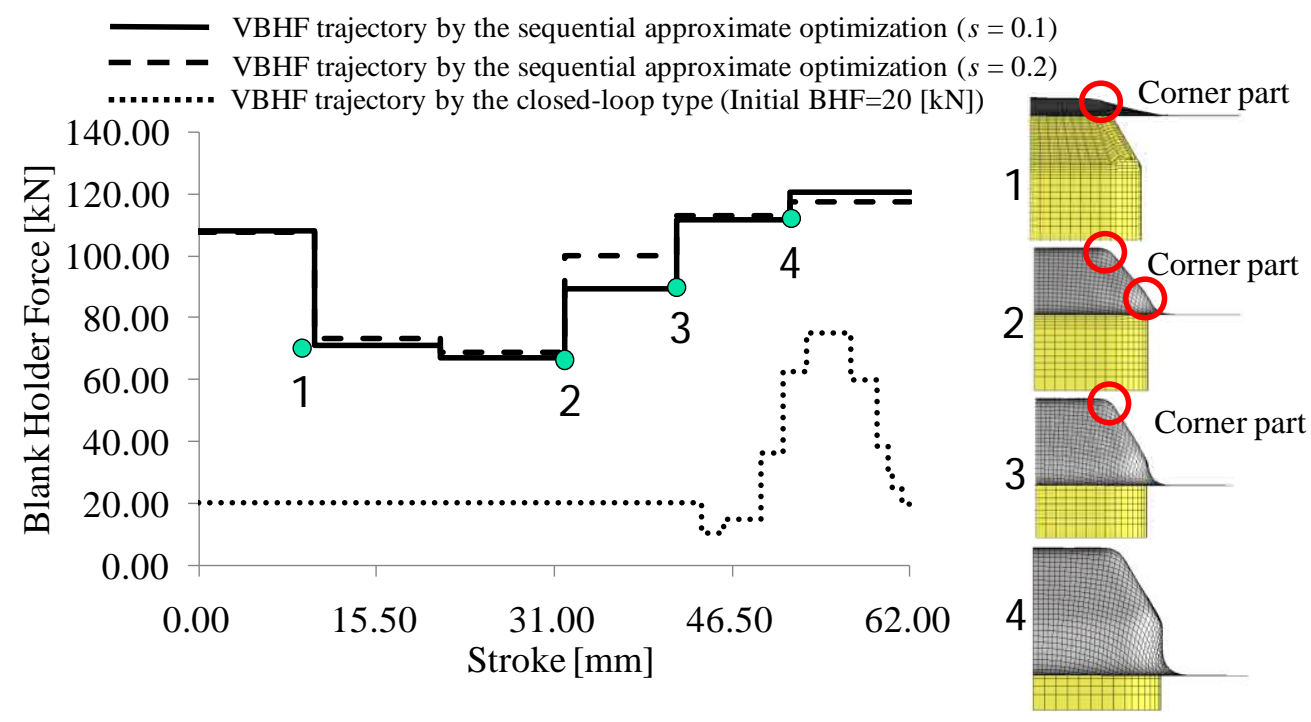

Fig.13 Optimal VBHF trajectories

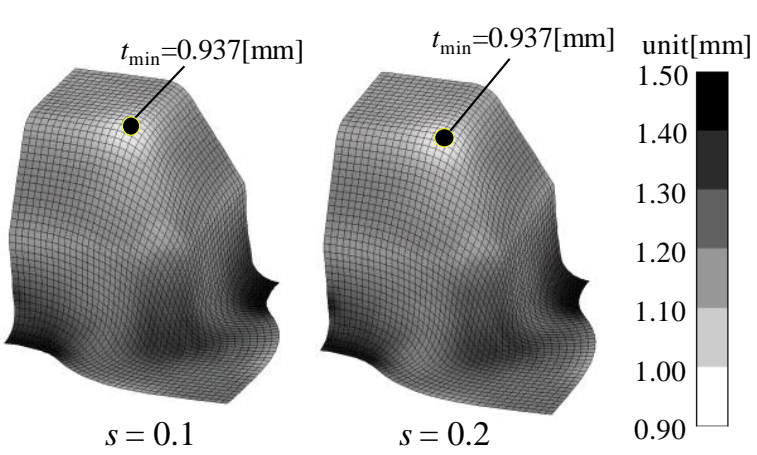

Fig.14 Thickness distribution by the VBHF trajectory

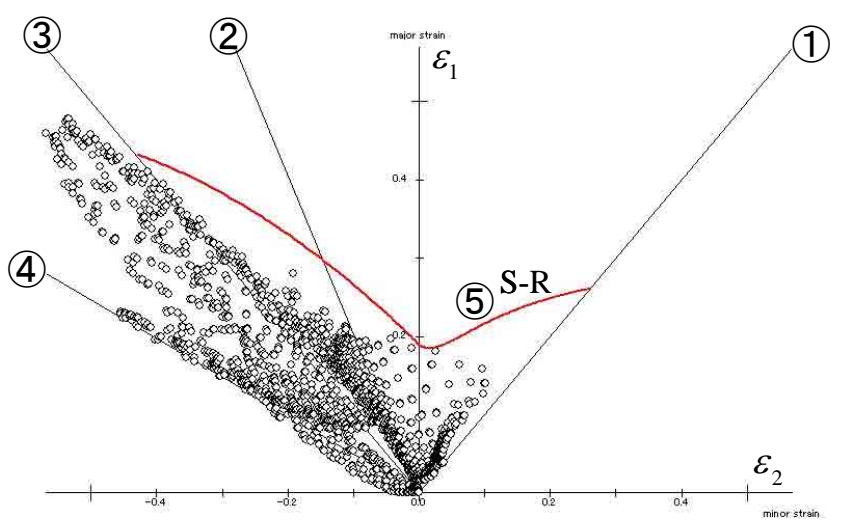

Fig.15 Forming Limit Diagram of the VBHF trajectory $(s=0.2)$

図 15 において, (1)はひずみ比が $\varepsilon_{2} / \varepsilon_{1}=1$ となる等二軸引張線, (2)はひずみ比が $\varepsilon_{2} / \varepsilon_{1}=-r /(1+r)$ となる単軸引 張線, (3)はひずみ比が $\varepsilon_{2} / \varepsilon_{1}=-1$ となる純粋せん断線, (4)はひずみ比が $\varepsilon_{2} / \varepsilon_{1}=-(1+r) / r$ となる単軸圧縮線を表 す. なお， $r$ は表 1 に示した異方性パラメータである.さらに(5)はStoren-Rice の局所くびれ理論に基づく成形限 界線を表す ${ }^{(23) .}$

図 13 より，式(10)，(11)のパラメータ $s$ は本論文で設定した值においては，VBHF の最適軌道には大きな影響 を与えていないことがわかる. また成形状態を考えると, 板材がパンチ角部に当たるとき (図 13 右中の丸印)に, BHF は低くなっており，ストロークが進むにつれ，徐々にBHF が大きくなっている．本論文で用いたパンチ形 状では，板材はパンチ角部で最も薄くなり，割れの発生しや寸い箇所であるため，板材がパンチ角部に接触する と，材料を積極的に金型内に流入させ，割れの発生を防ぐよう BHF が低くなっているものと考えられる. またス 
トロークが進むにつれ，BHFが大きくなるのは，角部の成形が終了した後は，金型内への材料流入を防ぎ，しわ の発生を抑制するためと考えられる，実際の成形加工の現場では，「決押し」と呼ばれており (24)，本論文で求め た VBHF の最適軌道は, 経験的に行われていた成形加工法と定性的に一致する.

次に図 14 について考えると，シミュレーション上で割れが発生すると仮定した $0.90 \mathrm{~mm}$ を上回っている.さら に図 15 に示した FLDにおいても, 割れが発生寸ると想定される領域において, 有限要素が存在していないこと から，シミュレーション上では，割れは発生していないと考えられる．また，ブランクホルダーとダイスの距離 は1.40mmであり，しわは発生していないと判断できる。応答曲面の最適解とシミュレーションの誤差を表 5 に 示寸.

Table 5 Errors between response surface and numerical simulation

\begin{tabular}{c|c|c|c|c}
\hline \hline & $s$ & $f(\boldsymbol{x})$ & $\begin{array}{c}g_{1}(\boldsymbol{x}) \\
\text { (Tearing) }\end{array}$ & $\begin{array}{c}g_{2}(\boldsymbol{x}) \\
(\text { Wrinkling) }\end{array}$ \\
\hline \multirow{2}{*}{ Reponse Surface } & 0.1 & $6.29 \mathrm{E}-01$ & $7.68 \mathrm{E}-03$ & $6.24 \mathrm{E}-02$ \\
\cline { 2 - 5 } & 0.2 & $6.40 \mathrm{E}-01$ & $3.55 \mathrm{E}-02$ & $1.00 \mathrm{E}-01$ \\
\hline \multirow{2}{*}{ Numerical Simulation } & 0.1 & $6.12 \mathrm{E}-01$ & $7.80 \mathrm{E}-03$ & $6.34 \mathrm{E}-02$ \\
\cline { 2 - 5 } & 0.2 & $5.97 \mathrm{E}-01$ & $3.50 \mathrm{E}-02$ & $1.02 \mathrm{E}-01$ \\
\hline \multirow{2}{*}{ Error [\%] } & 0.1 & 2.86 & 1.53 & 1.49 \\
\cline { 2 - 5 } & 0.2 & 7.09 & 1.43 & 1.84 \\
\hline
\end{tabular}

\section{$4 \cdot 2$ 制約条件がーつの場合}

文献等では，しわと割れを併せて一つの評価項目としている，そこで，制約条件の扱いが VBHF の最適軌道に 与える影響を調べるため，しわと割れを一つの制約条件としてVBHF の軌道を求めてみる，具体的には，次のよ うにして制約条件值を求めることになる。

$$
\begin{aligned}
& g_{1}(\boldsymbol{x})=\left(\sum_{j=1}^{m} G_{j}\right)^{1 / p} \\
& \text { ただし, } \\
& \qquad\left\{\begin{array}{cc}
G_{j}=\left(\varepsilon_{1}^{j}-\theta_{T}\left(\varepsilon_{2}^{j}\right)\right)^{p} & \varepsilon_{1}^{j}>\theta_{T}\left(\varepsilon_{2}^{j}\right) \\
G_{j}=\left(\theta_{W}\left(\varepsilon_{2}^{j}\right)-\varepsilon_{1}^{j}\right)^{p} & \varepsilon_{1}^{j}<\theta_{W}\left(\varepsilon_{2}^{j}\right) \\
0 & \text { otherwise }
\end{array}\right.
\end{aligned}
$$

である. 式(24), (25)中の $p$ は, $p=4$ とし, 初期サンプル点配置, 逐次近似最適化が終了する最大サンプル点数 は同じとした. 式(10), (11)中の $s$ を $s=0.2$ としたときの VBHF の最適軌道を図 16 中の実線で示す.また, 成形 終了時における板厚分布を図 17 に示す.

図 16 より，制約条件の取り扱いにより，VBHFの最適軌道は大きく異なることがわかる．また図 17 より，板 厚の最小值は，制約条件が二つの場合に比べ，小さくなっており，割れの危険性が増していることが分かる．式 (24)，(25)から明らかなように，しわと割れを一つの制約条件として扱うと，どちらの危険性が高いのかを明らか にすることはできない，その結果，板厚の最小値は，しわと割れを一つの制約条件として扱った場合，しわと割 れを個別の制約条件として扱った場合に比べ，小さい值をとっている.

本節の数值計算結果は，しわと割れを制約条件として扱う場合，個別の制約条件として扱うことが有効である ことを示唆しており，これは，しわや割れを目的関数として考える場合も個別に考えることが有効であることを 示唆しているものと考えられる. 

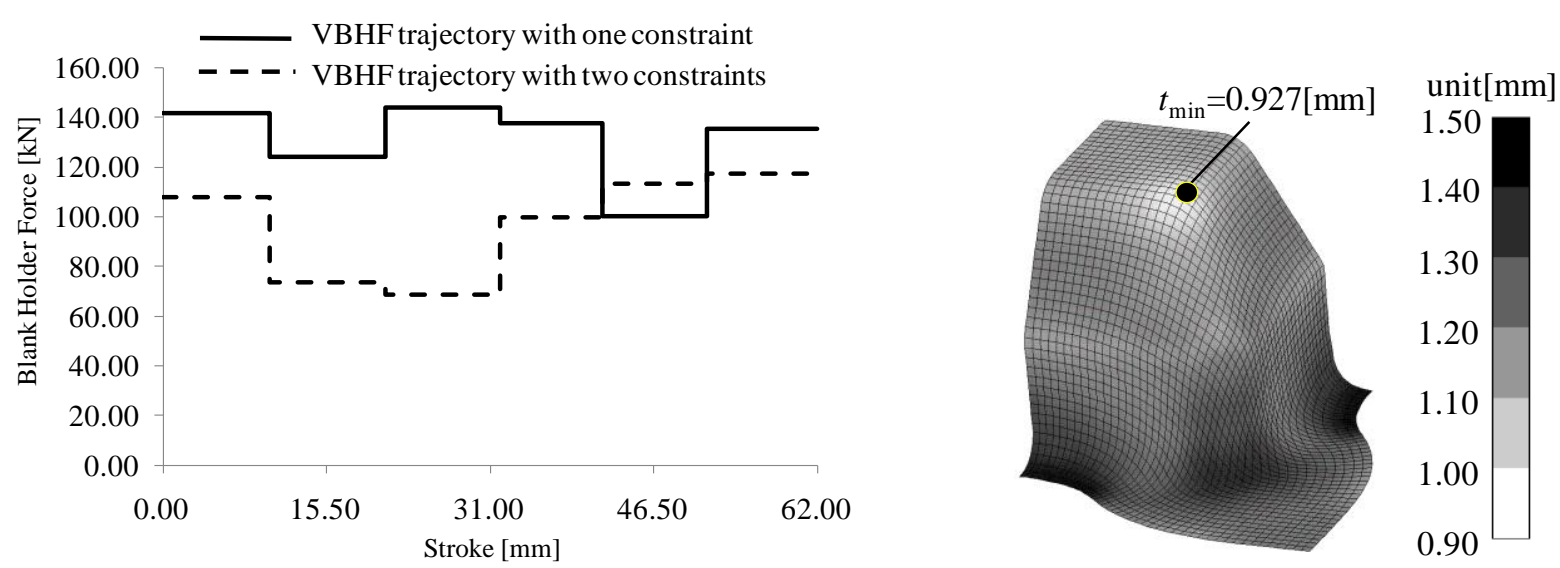

Fig,16 VBHF trajectory with one constraint

Fig.17 Thickness distribution with one constraint

\section{$4 \cdot 3$ 閉ループ型アルゴリズムとの相違・類似について}

筆者らは本論文で扱った解析モデルに対して，しわや割れを防ぎっつ，板厚変動を既定值以下に抑えるような VBHF の軌道を得るアルゴリズムを提案し，シミュレーションおよび実機による試験を通じ，その有効性を検討 した。一方，本論文では，目的関数や制約条件を定量的に定義し，逐次近似最適化によりVBHF の最適軌道を求 めた．図 13 に，初期 $\mathrm{BHF}=20 \mathrm{kN}$ としたときの閉ループ型アルゴリズムによる VBHF の軌道と，逐次近似最適化 による VBHF の最適軌道が示されており，これらの相違・類似について考察する.

閉ループ型アルゴリズムで VBHF の軌道を求める場合, 成形加工中の板材の状態を常に検討寸ることにより, 細かな BHF の制御が可能である．閉ループ型アルゴリズムでは，板厚変動を既定值以下に抑えるように BHFを 変化させる満足化設計であり, また成形開始からしばらくの間 (ストローク長が $40 \mathrm{~mm}$ 程度まで) は, 一定の BHF である，すなわち，ストローク長が $40 \mathrm{~mm}$ 程度までは，板厚変動が既定值以下であり，さらにしわや割れが発生 しておらず，諸条件を満足した状態で成形加工が行われていることを意味している.

一方，本論文で用いた逐次近似最適化によるVBHF の最適軌道は，閉ループ型アルゴリズムによって得られた VBHF の軌道に比べ,頻繁にBHF が上下に変動している. 本論文では, 目的関数や制約条件を定量的に定義して, 応答曲面を構築し，応答曲面の最適解を求めている。一般に制約条件がある最適化問題では，一つ以上の制約条 件がアクティブ（活性）な状態で最適解が得られることを考慮すれば, 最終的に得られた VBHF の最適軌道は, 満足化によるアプローチとは異なり，しわや割れが発生する限界に近い状態として得られたものと考えられる. このことは表 5 の割れに関する制約条件值がアクティブとなっていることからも明らかであり，割れの発生を極 力抑える軌道となっている.

両アプローチによるVBHF の軌道の相違は, 満足化と最適化の相違が明確に現れた結果であり，また成形過程 の板厚の変動を常に考慮したアプローチと, 成形前後の状態から板厚の変動を最小化するアプローチの差でもあ ると考えている，一方，ストロークが最終段階に近づくにつれ，BHFが一旦大きくなっているという現象は，共 通した点である，これは寸でに述べたように，成形加工の現場で言われている「決押し」を表しているものと考 えられ，両アプローチとも，経験を裏付ける結果を出しているものと考えられる.

\section{5. 結言}

本論文では，角筒深絞り加工を対象として，割れやしわの発生の危険性を制約条件，全ストロークを分割し， 各ストロークにおける BHF の大きさを設計変数とし, 成形加工中の板厚変動を最小化するような VBHF の最適 軌道を RBF ネットワークを用いた逐次近似最適化により求めた.

逐次近似最適化によって得られた VBHF の最適軌道は, 定性的には M 字に近く, これは本論文で扱ったパン チ形状における成形加工において, 経験的によいといわれているものと極めて近いものとなり, 経験則を裏付け る結果となったものと考えている。また本論文で求めた VBHF の最適軌道と閉ループ型アルゴリズムによる VBHF の軌道では, 最適化と満足化の相違が表れた結果と考えられる. また, 安全係数の值によってVBHF の最 適軌道は非常に類似したものとなった. 
塑性加工のような非線形性の強い現象に対し，数理計画法に代表される勾配法を用いることは，計算時間や微 分可能性の問題等から得策ではなく，本論文で示した応答曲面による方法が有効であろう．実務への応用につい て言及すれば，しわや割れが発生する BHF を事前に把握して設計変数の下限值および上限值を決めておき, 逐次 近似最適化を用いることで, 近似的ではあるもののしわや割れの発生を抑え, 板厚変動を最小にするような最適 な VBHF 軌道を設計できる.

本研究を進めるにあたり, 渡辺聖司氏（(株）コマツプレス・工機事業本部，技管・解析グループ長）には，適 切なご助言をいただいた。この場を借り，感謝申し上げる.

\section{付 録}

本論文では, しわや割れの危険性を成形限界線図を用いて定量化している. 図 15 はプレス成形シミュレーショ ンシステムJSTAMPを用いている. 図 15 中の(5)以下の式によって求めることができる.

$$
\varepsilon_{1}=\left\{\begin{array}{cc}
\frac{n}{(1+\beta)\left\{\frac{1-n}{2}+\left[\frac{(1+n)^{2}}{4}-\frac{\beta n}{(1+\beta)^{2}}\right]^{\frac{1}{2}}\right\}} & -1 \leq \beta \leq 0 \\
\frac{3 \beta^{2}+n(2+\beta)^{2}}{2(2+\beta)\left(1+\beta+\beta^{2}\right)} & 0 \leq \beta \leq 1
\end{array}\right.
$$

ただし， $\beta=\varepsilon_{2} / \varepsilon_{1}$ である.ここで $n$ は表 1 に示す加工硬化係数である. ここで上式を展開し， $\varepsilon_{1}$ について解 くと次のようになり，図 15 中の(5)を書くことができる.

$$
\varepsilon_{1}=\left\{\begin{array}{cc}
\frac{1}{2}\left(-1-\varepsilon_{2}+n+\sqrt{A}\right) & \varepsilon_{2} \geq 0 \\
\frac{1}{6}\left[\left(-3 \varepsilon_{2}+2 n\right)-\frac{9 \varepsilon_{2}^{2}-4 n^{2}}{B}+B\right] & \varepsilon_{2}<0
\end{array}\right.
$$

ただし，

$$
\begin{aligned}
& A=1-2 \varepsilon_{2}-3 \varepsilon_{2}^{2}+2 n+2 \varepsilon_{2} n+n^{2} \\
& B=\{C+9 \sqrt{D}\}^{\frac{1}{3}}
\end{aligned}
$$

であり，

$$
\begin{aligned}
& C=81 \varepsilon_{2}^{2}-27 \varepsilon_{2}^{2} n+8 n^{3} \\
& D=81 \varepsilon_{2}^{4}+9 \varepsilon_{2}^{6}-54 \varepsilon_{2}^{4} n-3 \varepsilon_{2}^{4} n^{2}+16 \varepsilon_{2}^{2} n^{3}
\end{aligned}
$$

である.

(1) Wang, W.R., Chen, G.L., Lin, Z.Q., Li, S.H., "Determination of optimal blank holder force trajectories for segmented binders of step rectangle box using PID closed-loop FEM simulation", International Journal of Advanced Manufacturing Technology, Vol.32, (2007), pp.1074-1082. 
(2) Obermeyer, E.J., Majlessi, S.A., "A review of recent advances in the application of blank-holder force towards improving the forming limits of sheet metal parts", Journal of Materials Processing Technology, Vol.75, (1998), pp.222-234.

(3) Lin, Z.Q., Wang, W.R., Chen, G.L., "A new strategy to optimize variable blank hoder force towards improving the forming limits of aluminum sheet metal forming", Journal of Material Processing Technology, Vol.183, (2007), pp.339-346.

(4) Sheng, Z.Q., Jirathearanat, S., Altan, T., "Adaptive FEM simulation for prediction of variable blank holder force in conical cup drawing", International Journal of Machine Tools \& Manufacture, Vol.44, (2004), pp.487-494.

(5) Hsu, C.W., Ulsoy, A.G., Demeri, M.Y., "An approach for modeling sheet metal forming for process controller design", Trans. of ASME/ Journal of Manufacturing Science and Engineering, Vol.122, (2000), pp.717-724.

(6) Traversin, M., Kergen, R., "Closed-loop control of the blank-holder force in deep-drawing: finite-element modeling of its effects and advantages", Journal of Materials Processing Technology, Vol.50, (1995), pp.306-317.

(7) Sim, H.B., Boyce, M.C., "Finite element analyses of real-time stability control in sheet forming processes", Trans. of ASME/ Journal of Engineering Materials and Technology, Vol.114, (1992), pp.180-188.

(8) Lo, S.W., Yang, T.C., "Closed-loop control of the blank holding force in sheet metal forming with a new embedded-type displacement sensor", International Journal of Advanced Manufacturing Technology, Vol.24, (2004), pp.553-559.

(9) 北山哲士，濱野智史，山崎光悦，久保達男，西川輝，木下洋，”可変ブランクホルダー力による角筒深絞り加工”, 日本機械学会論文集 C 編, Vol.76, No.766, (2010), pp.1617-1626.

(10) Chengzhi, S., Guanlong, C., Zhongqin, L., "Determining the optimum variable blank-holder forces using adaptive response surface methodology (ARSM)", International Journal of Advanced Manufacturing Technology, Vol.26, (2005), pp.23-29.

(11) Wei, L., Yuying, Y., "Multi-objective optimization of sheet metal forming process using pareto-based genetic algorithm", Journal of Materials Processing Technology, Vol.208, (2008), pp.499-506.

(12) Jansson, T., Nilsson, L., Redhe, M., "Using surrogate models and response surface in structural optimization -with application to crashworthiness design and sheet metal forming", Structural and Multidisciplinary Optimization, Vol.25, (2003), pp.129-140.

(13) Jansson, T., Andersson, A., Nilsson, L., "Optimization of Draw-in for an Automotive Sheet Metal Part An Evaluation Using Surrogate Models and Response Surfaces", Journal of Materials Processing Technology, Vol.159, (2005), pp.426-436.

(14) Wang, H., Li, G.Y., Zhong, Z.H., "Optimization of sheet metal forming processes by adaptive response surface based on intelligent sampling method", Journal of Materials Processing Technology, Vol.197, (2008), pp.77-88.

(15) Breitkopf, P., Naceur, H., Rassineux, A., Villon, P., "Moving least squares response surface approximation: Formulation and metal forming applications", Computers and Structures, Vol.83, (2005), pp.1411-1428.

(16) Wang, H., Li, E., Li, G.Y., "Optimization of drawbead design in sheet metal forming based on intelligent sampling by using response surface methodology", Journal of Materials Processing Technology, Vol.206, (2008), pp.45-55.

(17) Wang, H., Li, E., Li, G.Y., "Parallel Boundary and Best Neighbor Searching Sampling Algorithm for Drawbead Design Optimization", Structural and Multidisciplinary Optimization, Vol.41, (2010), pp.309-324.

(18) Jakumeit, J., Herdy, M., Nitsche, M., "Parameter optimization of the sheet metal forming process using an iterative parallel Kriging algorithm", Structural and Multidisciplinary Optimization, Vol.29, (2005), pp.498-507.

(19) Tang, Y., Chen J., "Robust Design of Sheet Metal Forming Process Based on Adaptive Importance Sampling", Structural and Multidisciplinary Optimization, Vol.39, (2009), pp.531-544.

(20) Naceur, H., Ben-Elechi, S., Batoz, J.L., Knopf-Lenoir C., "Response surface methodology for the rapid design of aluminum sheet metal forming parameters", Materials and Design, Vol.29, (2008), pp.781-790.

(21) Kurtaran, H., Eskandarian, A., Marzougui, D., Bedewi, N.E., "Crashworthiness Design Optimization Using Successive Response Surface Approximations", Computational Mechanics, Vol.29, (2002), pp.409-421.

(22) 北山哲士，荒川雅生，山崎光悦，”RBFネットワークによる逐次近似最適化（サンプル関数の基礎的検討）”，日本 機械学会論文集 C 編, Vol.76, No.768, (2010), pp.1978-1987.

(23) Storen, S., Rice, J., "Localized Necking in Thin Sheets", Journal of the Mechanics and Physics of Solids, Vol.23, (1975), pp.421-441.

（24）プレス成形難易ハンドブック（第 3 版），薄鋼板成形技術研究会(編), 日刊工業新聞社. 